\section{Asessing Parenting Education: Parenting Styles Of Adolescents In Rural And Urban Society}

\author{
Erna Nurkholida', Mukhammad Luqman Hakim² \\ Teacher Training Faculty ${ }^{1,2}$ \\ Islamic State Institute of Kediri, Indonesia \\ Email: ernanurkholida@ymail.com ${ }^{1}$
}

http://ojs.unm.ac.id/index.php/Insani/index

Abstract. The objective of this study is to find out the differences of parenting styles in rural and urban society toward with adolescent's involvement in family decision making. This research using a cross sectional survey method and embracing the theories of Montessori, Steinberg and Santrock about adolescent development, and Yusuf in parenting styles. The instrument used was adapted from the Alabama Parenting Questionnaire. It was consisted of 13 questions they were independency, responsibility, honesty, self-acceptance, receiving mistakes, trust, protection, freedom, involvement, and discipline. The result of rural society was the highest maximum value on the acceptance question (59\%), namely admitting mistakes. For urban society data showed that the highest score of the questionnaire is about the parenting style of acceptance with a value of $62 \%$. This meant that the result of the parenting style the child receives was the permissiveness style of care. The conclusion based on the area the urban society is more democratic in parenting. It makes teenagers more independent, confident and open minded.

Keywords: Adolescents, Parenting Styles, Urban, Rural.

\section{INDONESIAN JOURNAL OF EDUCATIONAL STUDIES (IJES)}

\section{E-ISSN: 2621-6744 \\ P-ISSN: 2621-6736}

Submitted: May, $19^{\text {th }} 2020$

Accepted: May, $29^{\text {th }} \mathbf{2 0 2 0}$

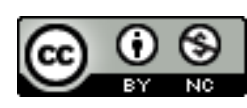

This work is licensed under a Creative Commons AttributionNonCommercial 4.0 International License 


\section{INTRODUCTION}

The pattern of parenting today is different from the past (Park \& Oh, 2012; Furstenberg et al., 1982; Darling \& Steinberg, 1993; Atalaia, 2019). The biggest influence from past and present differences is technology and follows overseas trends (Leavitt et al., 2020). The paradigm of the past states that children are miniature adults, they have no choice to carry out their desires and interests. In the digital era several conflicts have arisen in the face of this paradigm and reality. Parents still use their authority, style and ambition in children (Bruggeman et al., 2019). So many rebellions occur in children, especially teenagers, this can be seen from several cases of the escape of children who learn in islamic boarding school, children who skipped school and decreased levels of achievement in certain subjects all because children do not like learning there and forced by their parents. For this condition, children need to be listened to and asked for their needs, therefore children must develop according to their development. The development of adolescents has a dynamic influence on their lives in the future. Development by developing a variety of potentials that they have optimally, will bring a good impact on children's cognitive and emotional development.

Montessori in Johnston(2016) describes the stages in which children develop as the Four Areas of Development: childhood (I), childhood (II), adolescents (III), and maturity (IV). Teenagers are in the third position is a critical stage for adults who will become children. Montessori in Johnsom 92016) wrote that the most important thing is the education of adolescents, which is important, because adolescence is a time when children are in a state of maturity and become members of society." Teenagers are socially newborn babies. Leaving childhood, the young man wanted to find a place as a valuable member of society.

Adolescence is a physical and social awkward period due to rapid growth and sexual maturation. Ewert-Krocker in Johnson (2016) explains that adolescence is a time of opposition. It means that teenagers are often not brave enough, or clear enough to take a moral risk. The foundation that youth builds during the first two areas of development, from childhood to childhood, is a stable element in which they can build. The limit adolescents to 12-21 years (Mongks et al., 2000). According to Stanley Hall in Santrock (2010) teenagers are in the range of 12-23 year. Based on the limitations given by experts, it can be seen that the beginning of adolescence is relatively the same, but the end of adolescence varies greatly. Some are even known as time periods, shortened adolescents and long adolescents. Adolescence is a period full of problems. This statement has long been stated in the early 2oth century by the Father of Adolescent Psychology, Stanley Hall (Steinberg \& Silk, 2002). He argued that this was a period of storm and stress. In addition, Erickson said that adolescence is a time of identity crisis or the search for self-identity. Erickson's idea was corroborated by James Marcia who found that there were four statuses of identity in adolescents namely diffusion/confusion of identity, moratorium, confiscation, and attainment of identity (Erikson, 1968). Characteristics of adolescents who are in the process of searching for self-identity also often cause problems in adolescents. With the maturation of sexual organs in adolescents will result in the emergence of sexual impulses. 
Among the changes that occur in adolescence that can affect the relationship between parents and adolescents like puberty, developing logical reasoning, increasing idealistic thinking, unreachable expectations, changes in school, peers, friendship, dating, and relations to freedom (Kim et al., 2001; Branje, 2018; Dimler et al., 2017). In China, many teenagers experience changes in behavior when they teenage years (Lu et al., 2020). Some conflicts that usually occur between adolescents and parents usually revolve around problems of daily life such as time to go home, how to dress, tidy up the bedroom. Such conflicts rarely pose a big dilemma compared to drug use or juvenile delinquency. Another problem between teens and parents is about the way parents treat those who are authoritarian, or the attitude of parents who are too rigid or do not understand the interests of teenagers.

\section{Adolescence}

Psychologically, adolescence is the age at which individuals integrate with adult society, the age at which children no longer feel below the level of older people but are at the same level, at least in terms of integration in society (adults) have effective aspects, more or less related to puberty, including striking intellectual change. The intellectual transformation that is typical of this way of thinking of adolescents enables it to achieve integration in adult social relations, which is in fact a common characteristic of this developmental period. The same thing also stated by Jhon W. Santrock, adolescence is a period of developmental transition from childhood to adulthood which includes biological, cognitive, and social emotional changes (Erikson, 1968). Physically, adolescence begins with the onset of puberty around 12 or 13 and peaks at adulthood at around 19 or 20 . There are individual differences in the timing of puberty and the beginning of physiological body changes, with girls generally starting earlier than boys guys. Puberty brings new sexual feelings and this natural need to integrate into a sense of self and to establish sexual relations. The time of puberty change tends to be important for a group of adolescent peers status and influence the social and psychological responses that he receives from others (Darling et al., 2020). The teenage period is a period in life that we generally associate with self-exploration and the search for identity.

According to Erikson, it is not until one teenager has the mental or psychological capacity to handle the task of forming identity (Erikson, 1968). The social context of adolescents presents young women and men with the same challenges and pressures (eg work, gender roles and behavior) and different (e.g. body image). A key aspect of the youth dilemma is that it involves finding a role that not only fulfills self-attributes, but is also consistent with what the community expects. An adolescent's identity can therefore be seen as a result of mutual recognition by youth and society, with the community identifying possible alternative identities and influencing what is desired and what is not (Steinberg \& Silk, 2002).

So after understanding of some of the above theories, what is meant by adolescence is a transition from childhood to adulthood, with marked individuals have experienced developments or growths that are very rapid in all fields, which include physical changes that shows the maturity of the reproductive organs and the optimal functioning of other organs. Furthermore cognitive development that shows the way of adolescent thinking style, as well as adolescent social emotional growth. 
and all other developments experienced in preparation for entering adulthood. To enter adulthood stage, adolescent development has many factors that must be considered during their growth, including: relationships with their parents, relationships with peers, relationships with environmental conditions, and cognitive knowledge. In general, according to psychological figures, adolescents are divided into three age-limiting phases, namely; Early adolescent phase in the age range from 12-15 years; Middle adolescent phase in the age range of 15-18 years; Late adolescent phase in the age range 18-21 years.

So thus it can be known from the parts of age in adolescents which can be explained as follows, ages 12-15 years including early adolescents, ages 15-18 years middle adolescents, and late adolescents at the age of 18-21 years. By knowing the parts of adolescence we will more easily know the adolescent into his part, whether including early teens or middle teens and late teens. Maria Montessori has basic principles regarding the Montessori method, which is very focused on children as a center for children and adults as mentors. According Montesorri there are 4 basic principles of the Montessori method (Johnston, 2016), including:

a. Freedom

The Montessori method is based on freedom, namely freedom that is disciplined, free but disciplined. Freedom that seems not well understood throughout the world, basically humans have the power to feel the essential instincts of this freedom. This understanding means that a teenager should be free in determining his talents and choices by being given guidelines and limitations that guide them.

b. Independence

Independence is everything done by oneself. A person can be free, because he is independent, therefore, the first active manifestation of the independence of every child must be well guided, so that through this activity the child can achieve independence.

c. Reducing Rewards and Forming Punishment

The Montessori method does not use the form of gifts when children get success in their activities, because according to Maria Montessori gifts and forms of punishment will naturally follow. Humans who are disciplined through independence, begin to desire authenticity and the only gift is the emergence of human strength and independence in their souls that are the resources for their activities. When applied to children, the effect is to give freedom so that the child is active, when the child makes a mistake, the child realizes it and corrects the error, the error is used as a learning process in his life.

d. Discipline

Discipline must arise through independence and independence is an activity. This is a great principle. If discipline is based on freedom or freedom, then the discipline itself must be active. Discipline is not when someone is made silent like a mute person and made immobile like a paralytic. Such a method is not the meaning of discipline, but negation. From the principles above, in other words adolescents must be involved, listen to their development. In parenting, it not only shows and gives the world to them but also lets them feel their world and respect them. 
According to Stanley Hall (in Santrock, 2003) teenagers are in the range of 12-23 years. Based on the limitations given by experts, it can be seen that the beginning of adolescence is relatively the same, but the end of adolescence varies greatly. Some are even known as expanded adolescents, and shortened adolescents. Adolescence is a period full of problems. Adolescence is a time of storm and stress. In addition, Erickson (Year) said that adolescence is a period of identity crisis or the search for identity.

\section{Parenting}

Parenting requires a number of interpersonal skills and has great emotional demands, but very little formal education regarding this task. Most parents learn parenting practices from their own parents. Some of these practices they accept, but some they leave. Husband and wife may bring different views about childcare into marriage (Santrock, 2010). There are many various kinds of parenting. They are overprotecing. It makes children's behavior like feeling insecure, aggressive and spiteful, easy to feel nervous. Escape from reality,very dependent on others, always want to be cared for, being surrendered, easy to get angry, not responsible, lack of confidence, do not have a stance, be sensitive to criticism, selfish, and Experience homesickness etc. Permissiveness; It makes children's behavior like clever looking for a way out, can collaborate; confidence; prosecutor and no patient.

Acceptance; It makes children's behavior like want to cooperate, friendly, loyal, his emotions are stable, cheerful and optimistic, willing to accept responsibility, honest, can be trusted, ave a clear plan for achieving the future, know the real situation (objectively understanding his strengths and weaknesses). Domination; It makes children's behavior like Be polite and be very careful, Shy, docile, interior and easily confused, cannot work together. Submission: not obey, not responsible, aggressive and careless/negligent, be authoritarian, too confident. Punitiveness/Overdiscipline; It makes children's behavior like implusive, unable to make a decision, naughty, hostile or aggressive attitude. Based on the above background, the researcher determines the research problem namely; What are the differences of parenting styles of adolescents in rural and urban society?

\section{RESEARCH METHOD}

This study uses survey research design to collect data, which is a procedure in quantitative research in which researchers conduct surveys to a sample or to an entire population of people to describe attitudes, opinions, behavior, or characteristics of a population (Creswell 2014, 377). As explained in Creswell (2014), the type of survey design that has been used here is a cross-sectional survey design, in which 2 groups of urban youth and rural youth are taken in a sample of junior high school students ages 13-15 will be compared. Inferential statistics are needed to draw conclusions about the conditions that exist in a population from sample studies drawn from populations.

This research was conducted in two schools. The selected city school was a junior high school located in Surabaya, namely Al Falah Middle School, Jalan Ketintang Madya 81 Surabaya, chosen because most students come from big cities in Indonesia while the rural school is a junior high school located in Nganjuk Regency, 
namely Pomosda Nganjuk Middle School; Jl. Wahid Hasyim 304 Tanjung Anom Nganjuk, most of the students came from the nearest district, Nganjuk. The total population was 213 participants divided by 2; they are 105 hundreds of urban youth participants, and 108 rural youth participants. In this study, researchers adapted the Alabama Parenting Questionnaire (APQ) designed by Frick, P.J. 1991. It was taken 13 questions. The questionnaire that researchers used with adjustments was independency, responsibility, honesty, self acceptance, receiving mistakes, trust, protection, freedom, involvement, and disipline. Data analysis was performed using statistics descriptive and inferential method.

\section{RESULT AND DISCUSSION}

The results of the survey showed that based on SPSS data processing obtained on the parenting questionnaire from Junior High School of Pomosda stated the highest maximum value on the acceptance question (59\%), namely admitting mistakes. Based on the theory of Yusuf, parenting patterns with the type of parenting acceptance produce honest children, know the real situation (understand their strengths and weaknesses objectively. For the results of the inquiry questionnaire, data obtained with the highest value of 285 is on the question questionnaire negative is about the discipline in my question to stay outside the house when I am at home, this showed parenting style that is not too disciplined so that children can feel something positive that can make their own right decisions.

Table 1. Descriptive Statistics of Parenting Styles in Group $1^{\text {st }}$

\begin{tabular}{ccccccc}
\hline Questionnaires & $\mathrm{N}$ & $\begin{array}{c}\text { Me } \\
\text { an }\end{array}$ & $\begin{array}{c}\text { Med } \\
\text { ian }\end{array}$ & $\begin{array}{c}\text { Mo } \\
\text { de }\end{array}$ & $\begin{array}{c}\text { Percen } \\
\text { tage }\end{array}$ & $\begin{array}{c}\text { Std. } \\
\text { Devi } \\
\text { ation }\end{array}$ \\
\hline Independency & 108 & $\begin{array}{c}53.5 \\
0\end{array}$ & $\begin{array}{c}52.5 \\
0\end{array}$ & 52 & $50 \%$ & $\begin{array}{c}2.42 \\
9\end{array}$ \\
\hline Independency in negative & 108 & $\begin{array}{c}52.7 \\
5\end{array}$ & $\begin{array}{c}53.0 \\
\text { questions }\end{array}$ & 45 & $49 \%$ & 6.185 \\
\hline Transfer of Responsibilities & 108 & $\begin{array}{c}47 . \\
50\end{array}$ & $\begin{array}{c}44.0 \\
0\end{array}$ & 40 & $44 \%$ & $\begin{array}{c}10.14 \\
9\end{array}$ \\
\hline regarding Acceptance of & 108 & $\begin{array}{c}43 . \\
33\end{array}$ & $\begin{array}{c}43.0 \\
0\end{array}$ & 36 & $40 \%$ & $\begin{array}{c}7.50 \\
6\end{array}$ \\
\hline Honesty & 108 & $\begin{array}{c}54 . \\
33\end{array}$ & $\begin{array}{c}53.0 \\
0\end{array}$ & 53 & $50 \%$ & $\begin{array}{c}2.30 \\
9\end{array}$ \\
\hline Self-Acceptance & 108 & $\begin{array}{c}63 . \\
33\end{array}$ & $\begin{array}{c}63.0 \\
0\end{array}$ & 52 & $59 \%$ & $\begin{array}{c}11.50 \\
4\end{array}$ \\
\hline Receiving Mistakes & 108 & $\begin{array}{c}47 . \\
67\end{array}$ & $\begin{array}{c}41.0 \\
0\end{array}$ & 40 & $44 \%$ & 12.42 \\
\hline Submission of Trust & 108 & $\begin{array}{c}43 . \\
33\end{array}$ & $\begin{array}{c}44.0 \\
0\end{array}$ & 31 & $40 \%$ & $\begin{array}{c}12.01 \\
4\end{array}$ \\
\hline Questionnaire Overprotective / & 108 & $\begin{array}{c}44 . \\
67\end{array}$ & $\begin{array}{c}46.0 \\
\text { Too Protect }\end{array}$ & 40 & $41 \%$ & 4.163 \\
\hline Analysis of Freedom & & & & &
\end{tabular}




\begin{tabular}{ccccccc}
\hline Involvement with friends & 108 & $\begin{array}{c}42.5 \\
0\end{array}$ & $\begin{array}{c}42.5 \\
0\end{array}$ & 39 & $39 \%$ & $\begin{array}{c}4.95 \\
0\end{array}$ \\
\hline Involvement in Choices & 108 & $\begin{array}{c}45 . \\
00\end{array}$ & $\begin{array}{c}43.0 \\
0\end{array}$ & 37 & $42 \%$ & $\begin{array}{c}7.32 \\
6\end{array}$ \\
\hline Discipline or Punishment & 108 & $\begin{array}{c}47 . \\
00\end{array}$ & $\begin{array}{c}47.0 \\
0\end{array}$ & 37 & $44 \%$ & $\begin{array}{c}14.14 \\
2\end{array}$ \\
\hline
\end{tabular}

Table 2. Descriptive Statistics of Parenting Style in Group $2^{\text {nd }}$

\begin{tabular}{|c|c|c|c|c|c|c|}
\hline Questionnaires & $\mathrm{N}$ & Mean & Median & Mode & Percentage & $\begin{array}{c}\text { Std. } \\
\text { Deviation }\end{array}$ \\
\hline Independency & 105 & 51.00 & 53.50 & 54 & $49 \%$ & 4.290 \\
\hline $\begin{array}{l}\text { Independency in } \\
\text { negative questions }\end{array}$ & 105 & 51.00 & 51.00 & 51 & $49 \%$ & .816 \\
\hline $\begin{array}{c}\text { Transfer of } \\
\text { Responsibilities }\end{array}$ & 105 & 49.25 & $47 \cdot 50$ & 37 & $47 \%$ & 13.525 \\
\hline $\begin{array}{c}\text { regarding } \\
\text { Acceptance of } \\
\text { Honesty }\end{array}$ & 105 & 46.00 & 49.00 & 36 & $44 \%$ & 8.888 \\
\hline Self-Acceptance & 105 & 54.00 & 54.00 & 53 & $51 \%$ & 12.858 \\
\hline Receiving Mistakes & 105 & 65.33 & 60.00 & 56 & $62 \%$ & 12.858 \\
\hline Submission of Trust & 105 & 53.33 & 56.00 & 39 & $51 \%$ & 13.204 \\
\hline $\begin{array}{c}\text { Questionnaire } \\
\text { Overprotective / } \\
\text { Too Protect }\end{array}$ & 105 & 44.00 & 43.00 & 36 & $42 \%$ & 8.544 \\
\hline Analysis of Freedom & 105 & 46.33 & 46.00 & 43 & $44 \%$ & $3 \cdot 512$ \\
\hline $\begin{array}{l}\text { Involvement with } \\
\text { friends }\end{array}$ & 105 & 41.00 & 41.00 & 40 & $39 \%$ & 1.414 \\
\hline $\begin{array}{l}\text { Involvement in } \\
\text { Choices }\end{array}$ & 105 & 45.00 & 43.00 & 37 & $43 \%$ & 7.326 \\
\hline $\begin{array}{l}\text { Discipline or } \\
\text { Punishment }\end{array}$ & 105 & 45.00 & 45.00 & 37 & $43 \%$ & 11.314 \\
\hline
\end{tabular}

For Al Falah Surabaya Junior High School students who represent urban society the data showed as follows: the highest score of the questionnaire is about the parenting style of acceptance with a value of $62 \%$. Exactly on the question "I will answer the question after I am appointed by the teacher". This meant that the result of the parenting style the child receives was the permissiveness/acquisition style of care. Whereas the involvement questionnaire was 224, which was the involvement of the school selection that would be entered, which meant that there was leeway to try and think for children. The final conclusion regarding differences in the involvement of children in decision making is for both rural and urban adolescents alike to the pattern of care that is acceptance type while for those involved it has a difference that is in city adolescents on acquisition (permissiveness). 


\section{CONCLUSION}

The final conclusion regarding differences in the parenting styles regarding the involvement of children in decision making is for both rural and urban adolescents alike to the styles of care that is acceptance type meanwhile for those involved it has a difference that is in city adolescents on acquisition (permissiveness). Parenting styles do not have differences between rural and urban society because they have no limited world, namely smartphone which shares all good information in parenting. However, based on the area the urban society is more democratic in parenting. It makes teenager more independent, confident and open minded.

\section{REFERENCES}

Atalaia, S. (2019). Parenting in stepfamilies: revisiting the stepfather's role. Families, Relationships and Societies, 8(3), 379-394.

Branje, S. (2018). Development of parent-adolescent relationships: Conflict interactions as a mechanism of change. Child Development Perspectives, 12(3), 171-176.

Bruggeman, H., Van Hiel, A., Van Hal, G., \& Van Dongen, S. (2019). Does the use of digital media affect psychological well-being? An empirical test among children aged 9 to 12. Computers in Human Behavior, 101, 104-113. https://doi.org/10.1016/j.chb.2019.07.015

Creswell, J. W. (2014). Research Design: Qualitative, Quantitative, and Mixed Methods Approaches. SAGE.

Darling, K. E., Ranzenhofer, L. M., Hadley, W., Villalta, D., Kasper, V., \& Jelalian, E. (2020). Negative childhood experiences and disordered eating in adolescents in a weight management program: The role of depressive symptoms. Eating Behaviors, 101402. https://doi.org/10.1016/j.eatbeh.2020.101402

Darling, N., \& Steinberg, L. (1993). Parenting style as context: An integrative model. Psychological bulletin, 113(3), 487.

Dimler, L. M., Natsuaki, M. N., Hastings, P. D., Zahn-Waxler, C., \& Klimes-Dougan, B. (2017). Parenting effects are in the eye of the beholder: Parent-adolescent differences in perceptions affects adolescent problem behaviors. Journal of youth and adolescence, 46(5), 1076-1088.

Erikson, E. H. (1968). Identity: Youth and Crisis. Norton.

Furstenberg Jr, F. F., Spanier, G., \& Rothschild, N. (1982). Patterns of Parenting in the Transition from Divorce to Rennarriagem. In Women: A Developmental Perspective: Proceedings of a Research Conference (No. 82, p. 325). US Department of Health and Human Services, Public Health Service, National Institutes of Health.

Johnston, L. M. C. (2016). Examining a Montessori Adolescent Program through a Self-Determination Theory Lens: A Study of the Lived Experiences of Adolescents. Journal of Montessori Research, 2(1)

Kim, K. J., Conger, R. D., Lorenz, F. O., \& Elder Jr, G. H. (2001). Parent-adolescent reciprocity in negative affect and its relation to early adult social development. Developmental psychology, 37(6), 775 . 
Leavitt, C. E., Allsop, D. B., Busby, D. M., Driggs, S. M., Johnson, H. M., \& Saxey, M. T. (2020). Associations of mindfulness with adolescent outcomes and sexuality. Journal of Adolescence, 81, 73-86

Lu, W., Zhang, A., \& Mossialos, E. (2020). Parental migration and self-reported health status of adolescents in China: A cross-sectional study. E-Clinical Medicine, 22, 100371

Mongks, F. J., Knoers, A. M. P., \& Hadinoto, S. R. (2000). Psikologi perkembangan: Pengantar dalam berbagai bagiannya. Gadjah Mada University Press

Park, K. I., \& Oh, S. (2012). Effects of active parenting today based on goal attainment theory on parenting stress, parenting behavior, and parenting satisfaction in mothers of school-age children. Journal of Korean Academy of Nursing, 42(5), 659-670.

Santrock, J. W. (2010). Adolescence. McGraw-Hill

Steinberg, L., \& Silk, J. S. (2002). Parenting Adolescents. Edited by Marc H. Bornstein. Lawrence Erlbraum Associates 